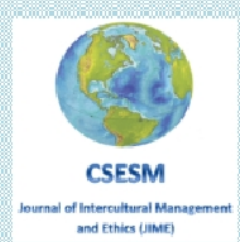

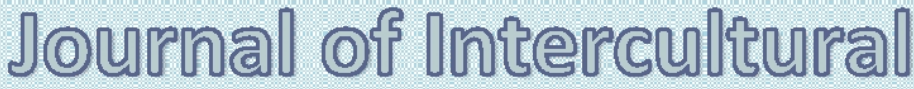

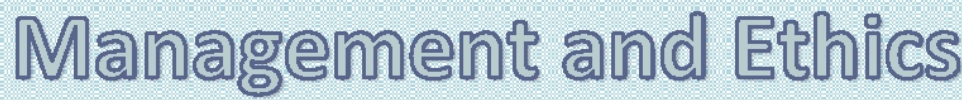

\author{
I0ME
}

ISSN 2601 - 5749, ISSN-L 2601 - 5749

Center for Socio-Economic Studies and Multiculturalism

lasi, Romania

WWW csesmioirg 


\section{TABLE OF CONTENT}

Editorial

Iulian Warter

Where Did Culture Come From? Evolutionary Foundations of Cultural Diversity

Paulo Finuras

Crash: Boeing and the Power of Culture

Thomas D. Zweifel, Vip Vyas

Political Culture, Social Polarization and Electoral Behavior. The Last Decade in Romanian

Political System

Silviu-Petru Grecu

The Principles of Transparency and Judging Others Favorably: The Talmudic View

Hershey H. Friedman, Robert B. Fireworker

Some Issues Regarding the Ethics of the Management at Romanian State-Owned

Companies .55

Baluta Aurelian Virgil, Rada Alexandru Cristian

How Does Logistics Command of the Military Navy Support Local Development and

Cultural Integration?

Rosa Caiazza

Illusion and Disillusion. Case Studies about the Constitution of a New Political Party in

Romania

Alexandru Muraru

How Could We Overcome the Feeling Of Insecurity? Explorations in the Spectrum of Polyscopic Consciousness

Anton Carpinschi

The Employees' Perceptions, Practices and Experiences Regarding the Strategic Process

Carried Out In the Public Hospitals

Ana Niculita 


\title{
POLITICAL CULTURE, SOCIAL POLARIZATION AND ELECTORAL BEHAVIOR. THE LAST DECADE IN ROMANIAN POLITICAL SYSTEM
}

\author{
Silviu-Petru Grecu, Ph.D. \\ Associate Professor, Faculty of Philosophy and Social-Political Sciences \\ University "Al.I.Cuza”, Iaşi, Romania \\ E-mail: silviu.grecu@uaic.ro
}

\begin{abstract}
The aim of this paper is to emphasize the role played by the political polarization and cultural variables in predicting "political apathy" or "alienation". In this context, the study has the main research objectives: 1 . to analyze the evolution of the electoral behavior in the last decade; 2 . to determine the relation between electoral behavior and cultural patterns; 3 . to estimate the magnitude of the relation between political polarization, political culture and the evolution of the on-line media. The research unit is represented by the Romanian political system in a long-term statistical series among 2010-2020. Empirical findings suggest that there is a degradation of the electoral participation in the last decade, with very high level of volatile rates. Moreover, this model of political behavior is related to historical past, cultural variables and geographical distribution. In this meaning, one of the most important variable for understanding the subject culture and political alienation is represented by the political polarization. Mathematical models estimate through a multi-linear equation of regression that political polarization affects negatively the evolution of the cultural variables and participative behavior $(\beta=-0.690, \mathrm{p}=0.029)$.
\end{abstract}

Keywords: political culture, political polarization, electoral behavior, deliberative democracy, on-line media

\section{Political culture and democracy. A model of complex interactions}

The aim of this paper is to present the relation between cultural patterns and the evolution of democracy. Beyond the traditional normative theory, democracy remains both a political ideal and a complex political reality. Scholars have analyzed democracy through several social and economic variables as economic growth, macro-economic stability, free market, social equality and political rights (Dahl, 2002; Dahl, 2000; Dahl, Shapiro, \& Cheibub, 2003). Recent findings from the theory of democratization emphasized the role played by economic freedom and free market in sustaining democratic order (Acemoglu \& Robinson, 2006; Aslund, 2010; Madison, 1998; Meusburger \& Heike, 2001; Przeworzki, 2001). But, all these empirical findings suggest a mechanical association between political order and economic development. Moreover, it is very important to create economic premises for democratic regime, but historical heritage and culture could predict the success of the democratic practices. In this respect, democracy should be seen as a complex process based on the interaction between endogenous factors and exogenous variables. We propose an analytical framework based on the importance of the endogenous variables in shaping different forms of democracy. At the endogenous level, political past and political culture could explain the main differences between full democracies and flawed democracies. Political culture represents the main psycho-sociological attitudes both implicit and explicit which characterize the social axiology and social practice. Political culture could be defined in terms of "the pattern of attitudes, values and beliefs about politics, whether they are conscious or unconscious, explicit or implicit" (Newton \& Wan Deth, 2009, p. 171). 
Political culture implies a subjective dimension related to the citizens' ability of interaction with the political regime and their affective relation with the political leadership. In practice, in the early of the ' 60 s Almond and Verba have identified three models of political culture: parochial model, subject culture and participative culture (Almond \& Verba, 1996). The last model is strongly related to democratic societies. A particular case of the participative model is based on the civic culture, which is defined through the complex interaction between individuals and governmental structure. This complex interaction differs from full democracies and hybrid political regimes, being influenced by social and psychosociological factors (Almond et al., 2004, pp. 58-60). In contemporary societies cultural variables are relevant for explaining different ways of democratic consolidation. Individual autonomy, secularization, social participation and civic engagement are several vectors for building a robust model of democratic regime (Inglehart \& Welzel, 2005). In practice, there are statistically significant correlations between individual values and the quality of the democracy with $\mathrm{r}=0.75, \mathrm{p}<0.01$. The same significant linear association is observed by Inglehard and Welzel between the quality of the democracy and the integrity of the political elite $(\mathrm{r}=0.90, \mathrm{p}<0.01)$ (Inglehart \& Welzel, 2005, p.151).

Related to the participative component of the political culture, we have to stress the role played by the social capital in generating an efficient pattern of social capital and civil society. Thus, democratic regime could be interpreted in terms of social capital, social participation to public affairs and civic engagement and opposition to governmental practices. Empirical case studies as Robert Putnam realized in the early of '90s demonstrated a linear relationship between the quality of democracy and civic participation to the public decision. Social engagement and individual enrollment in different social or non-governmental (NGO) structures is strongly associated to the participative and deliberative component of the democracy (Putnam, Leonardi \& Nanetti, 2001). The same conclusions are presented by Ulrich Beck, who presented, at the theoretical level, a model of civil society related to liberal democracy (Beck, 2007, p.61).

The social capital theory of democracy expresses the accord or collaboration of the citizens for optimal solving the public affairs (Han \& Dunn, 2005). Civil society could be seen as a permeable mechanism able to interact both with economic market and governmental actors (Anheier, 2004). The structure of the civil society depends on the historical past and cultural heritage (Henderson \& Vercseg, 2010). Western democracies are crystalized around a stable and strong pattern of civic action and civil society (Edwards, 2009).

Thus, this section argued that democratic order could be understood through endogenous variables which emphasize the role played by the individuals in the political system. This manner of defining and understanding democracy is based on a "spill-over" effect of the individuals. This could be seen as a centrifugal model, in which the center is represented by individuals' behavior, social values and political action.

\section{Political culture, social polarization and political behavior. Several psych-sociological regards}

The factual dimension of the political culture is reflected in the social and political behavior. All conscious and unconscious, implicit or explicit attitudes are related to an empirical framework of the political action: political behavior. In a general view, political behavior implies all the attitudes manifested in the political space, including in this context the lack of social action. Also, the lack of social or political action could be interpreted in terms of political "apathy" or social "alienation". Political behavior implies both the cognitions and attitudes regarding the political life and political space (Dalton \& Klingemann, 2011, p.322). At the theoretical level we can identify several perspectives which 
could explain the dynamics of the political behavior in social life. In this respect, the Marxist Theory explains the role played by the social class asymmetry in configuring political attitudes and beliefs related to the public space. The Elite Theory developed by Pareto and Mosca emphasizes the role played by the political elite in shaping political attitudes and beliefs. The Rational-Choice Theory analyses political behavior in terms of rationality and economic benefits regarding the political market. Social Capital Theory refers to, as we have explained in the first section of the article, the role played by the civil community in the public sphere (Newton \& Wan Deth, 2009, p.193-195).

In correlation with these theoretical perspectives we argue that social and psychological dimensions are relevant for explaining the political behavior. Although it is important to observe the role played by rational choice in social behavior, in practice there are several constraints generated by the emotional field of the human nature. This emotional field is met both in sociological and psychological perspective. However, the rational choice theory and economic design could complete this perspective based on the emotional factors. This article aims to develop an empirical framework based on sociological variables for explaining the cleavage between different types of political behavior. In our context it is very important to analyze the dichotomy between political activists and political alienation through a variable based on social and political polarization. In this meaning the social network and salient stimuli represented by the on -line media and networks could be an important catalysts for generating a specific model of political culture and a high degree of the social and political polarization.

The importance of the social network and media stimuli are explained in the early of the ' 60 by Lazarsfeld, who demonstrated the role played by the media in shaping social and political beliefs and patterns of political action (Lazarsfeld, Berelson \& Gaudet, 1968). Recent findings in the political sociology have demonstrated the role played by the social network in generating social polarization (Rowden, Lloyd \& Gilbert, 2014). Also, social context should be seen as the main channel for crystalizing political attitudes and beliefs (Antunes, 2010).

Related to the role played by media and social network in stimulating social beliefs and attitudes, we agree the fact that individuals are inserted in a kind of narration which could interfere with personal beliefs and cognitions (Hoewe \& Peacock, 2020). Changes and challenges from the virtual reality and digital media are related with the dimension of the affective polarization of the individuals which are exposed to social digital networks (Yarchi, Baden \& Kligler-Vilenchik, 2020). The high level of political socialization in on-line is related to personality, political ideologies and radicalization. Empirical studies estimated statistically significant correlations with the radicalization and violence (Moss \& O'Connor, 2020, p. 15-16).

On line media, socio-economic status and biological factors are involved in creating the polarization of the political attitudes and beliefs (Hout \& Maggio, 2021). Also, the selective exposure to social media creates premises for polarization regarding social or political aspects of the community life, but with several limits depending by the sociodemographic features of the individuals (Johnson, Kaye \& Lee, 2017; Levendusky \& Malhotra, 2015; Mellon \& Prosser, 2017). In other ways, cross-national studies reflect an important positive effect of the internet on the electoral behavior through the increased level of political information and social interaction (Song-In, 2007, p.381-395). The exposure to media, particularly to digital media, affects the interpersonal dialogue and the dynamics of the social capital (Zhang et al., 2010).

A particular case of polarization could be interpreted in terms of "affective polarization". Scientific studies argued that "that depictions of a divided populace transmitted through the mass media can increase perceived polarization. Polarized media coverage also 
moderates issue positions. At the same time, it increases affective polarization, thereby increasing the potential for partisan discord" (Levendusky \& Malhotra, 2015, p.14). One of the main factors which generate social and political polarization is represented by partisan media. Experimental studies demonstrated that selective exposure to partisan media could increase polarized attitudes for the citizens (Prior, 2013, p.104-111).

The main effect of the social and political polarization is registered in the sphere of the deliberation. In this context, polarization could be understood in terms of the lack of collaboration and consensus regarding different aspects of the social life. Psychological and ideological factors are involved in social polarization (Rekker, 2021). In accord with the ideological perspective political polarization could interfere with the quality of the political regime and the electoral dynamics (Tertytchnaya \& Lankina, 2020; Baila et al., 2020). In this respect, through mathematical models, scholars have demonstrated that a high level of political polarization erodes the quality of the democracy (Arbatli \& Rosenberg, 2020).

Synthetizing, this section presents several aspects regarding the relation between political behavior, political polarization and exposure to media, both in classical and digital manner. Although, in practice there are several significant advantages of the on-line media related to the increased capacity of information and possibility of social interaction, we have to present a critical view related to the negative impact on the deliberative component of the democracy. The selective exposure to partisan media is more likely to produce polarization. Rather, there is a high level of likelihood for radical opinions, beliefs and attitudes related to the public and ideological space. Recent empirical findings from the scientific literature could be an "early warning unit" for understanding the limits of the on-line partisan media and the negative influence of the political polarization in the sphere of the democratic order.

This kind of social and political polarization is translated in the political culture, creating premises for parochial or subject political culture, specific to hybrid or authoritarian political regimes. Political consensus and predisposition for deliberation, social dialogue and tolerance could be seen as vectors for participative culture and democratic political regimes.

\section{Research Methods}

The aim of the study is to create a deep image of the evolution of electoral behavior in Romanian political system. Although it is obviously that electoral behavior is strongly related to sociotropic voter, political heritage and cultural variables could create a comprehensive framework of the political evolution. Thus, the main research objectives are: 1 . to analyze the evolution of the electoral behavior in the last decade; 2. to determine the relation between electoral behavior and cultural patterns; 3 . to estimate the magnitude of the relation between political polarization, political culture and the evolution of the on-line media. The study starts from the research questions as: "how political culture could influence the electoral participation in Parliamentary and Presidential Elections" and "is the political polarization the main factor which influences the decreased level of the political participation?" In correlation with these theoretical issues we intend to test the hypothesis that $\mathrm{H} 1$ : Political polarization is strongly related to a decreased level of the electoral participation.

The research design is quantitative, data being extracted from secondary sources. The research method is the case study in a long-term statistical series: 2010-2020. In this meaning we used statistical indicators related to political behavior, participation, culture, democracy and on-line media from governmental and academic statistical sources. All quantitative data have normal distribution with Kolmogorov-Smirnonv Test $>0.05$.

\begin{tabular}{|c|c|c|}
\hline Variable & Symbol & Data sources: \\
\hline Polarization of the society & $\mathrm{X}_{1}$ & $\begin{array}{lrr}\text { Varieties } & \text { of } & \text { Democracy } \\
\text { Institute } & (\mathrm{V} & \text { DEM }),\end{array}$ \\
\hline
\end{tabular}




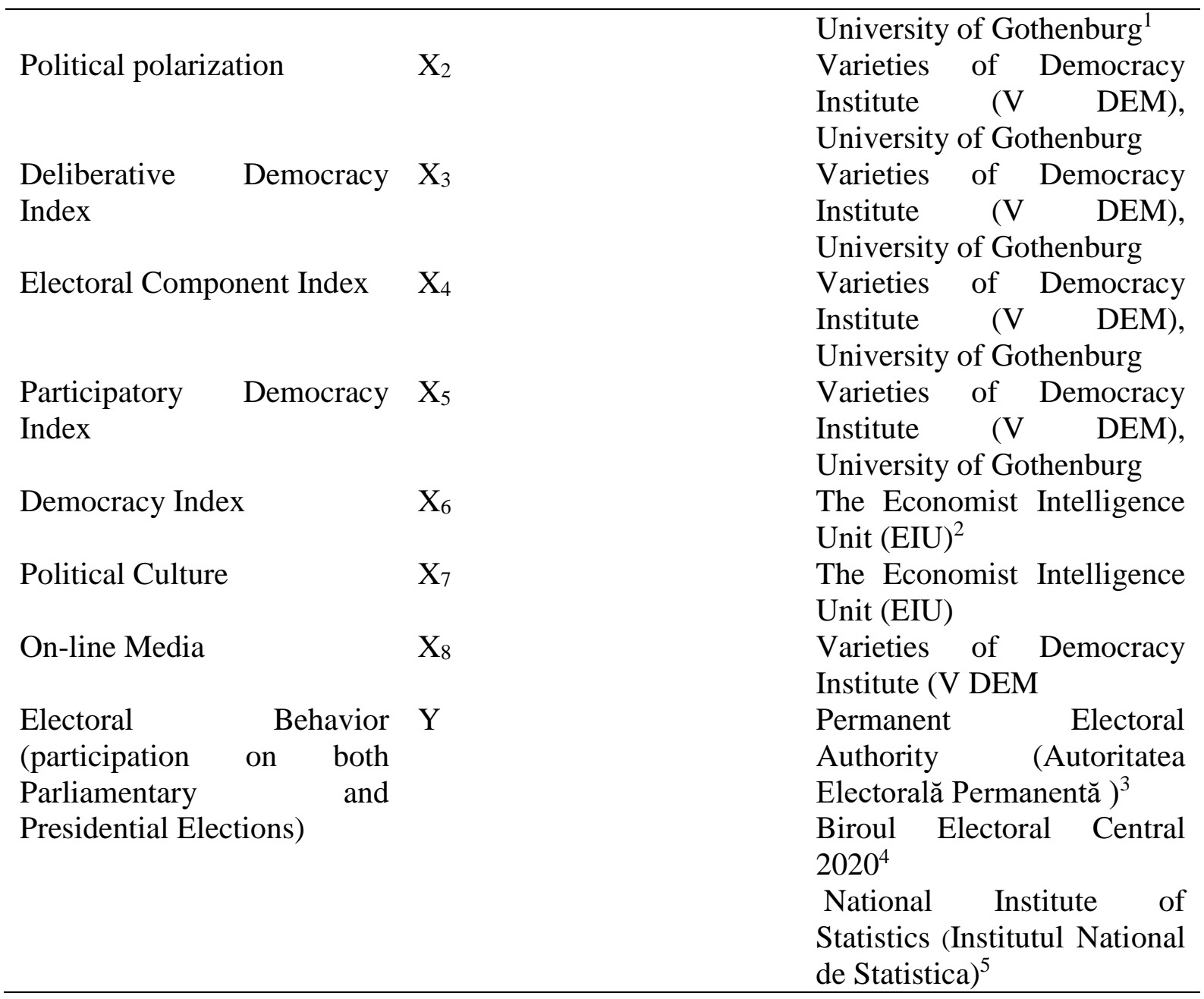

For testing the research hypothesis we propose the following quantitative design:

Let be $X=\left\{X_{1} \ldots \ldots \ldots \ldots X_{8}\right\}$ and $X_{1,2,6,7,8} \in[1 ; 10], X_{3,4,5} \in[0 ; 1]$ and $Y \in[0 ; 100]$, and $\mathrm{X}=\left\{\mathrm{X}_{1} \ldots \ldots \ldots \ldots \mathrm{X}_{8}\right\}=$ exogenous variables of the model and $\mathrm{Y}=$ endogenous variable.

The simple linear model is:

$$
f: X \rightarrow Y \text { and } f(x)=y
$$

Let be $\mathrm{C}$ - matrix $\left(\mathrm{M}^{*} \mathrm{M}\right)$, for the coefficients of correlation $\mathrm{X} \cap Y, \mathrm{U}=$ coefficient of residuals, $\mathrm{t}=$ unit of time, the mathematical model is:

$$
\begin{aligned}
& Y i=f(X i, \beta)+U i(1) \text { and } \\
& Y t=\sum_{i=1}^{n} \alpha Y t-1+\sum_{i=0}^{n} \beta X t-i+U t(2)
\end{aligned}
$$

From (1) and (2) we propose the equations:

$$
\begin{aligned}
& \text { 1. } Y i=\alpha+\beta 1 * x 1+\beta 2 * x 2+\beta 7 x 7+\beta 8 x 8+U i \text {, where } U i=\text { residuals } \\
& \text { 2. } Y i=\alpha+\beta 3 * x 3+\beta 4 x 4+\beta 5 x 5+\beta 6 x 6+U i
\end{aligned}
$$

\section{Subject culture, political polarization and electoral behavior in Romania}

\footnotetext{
${ }^{1}$ https://www.v-dem.net/

${ }^{2}$ https://www.eiu.com

${ }^{3}$ https://www.roaep.ro/

${ }^{4}$ https://parlamentare2020.bec.ro/

${ }^{5} \mathrm{https}$ ://insse.ro/cms/
} 
In accord with the methodological guidelines, we have observed the deterioration of the electoral participation in both types of elections (Parliamentary and Presidential) during 2012-2020. In this respect, we have observed that the interest of the citizens related to the public space has a low statistical rate, with a very high variation between the beginning of the temporal statistical series and 2020. If we model through a differential equation the relation between the evolution of the political participation in 2012 and 2020 in Parliamentary elections we can observe several aspects as: a negative impact on the political behavior with $(1-\alpha)=[26.19 ; 42,84]$, with negative Skewness and Kurtosis distribution $(-0.11 ;-0.19)$ and $\sigma=8.08$.

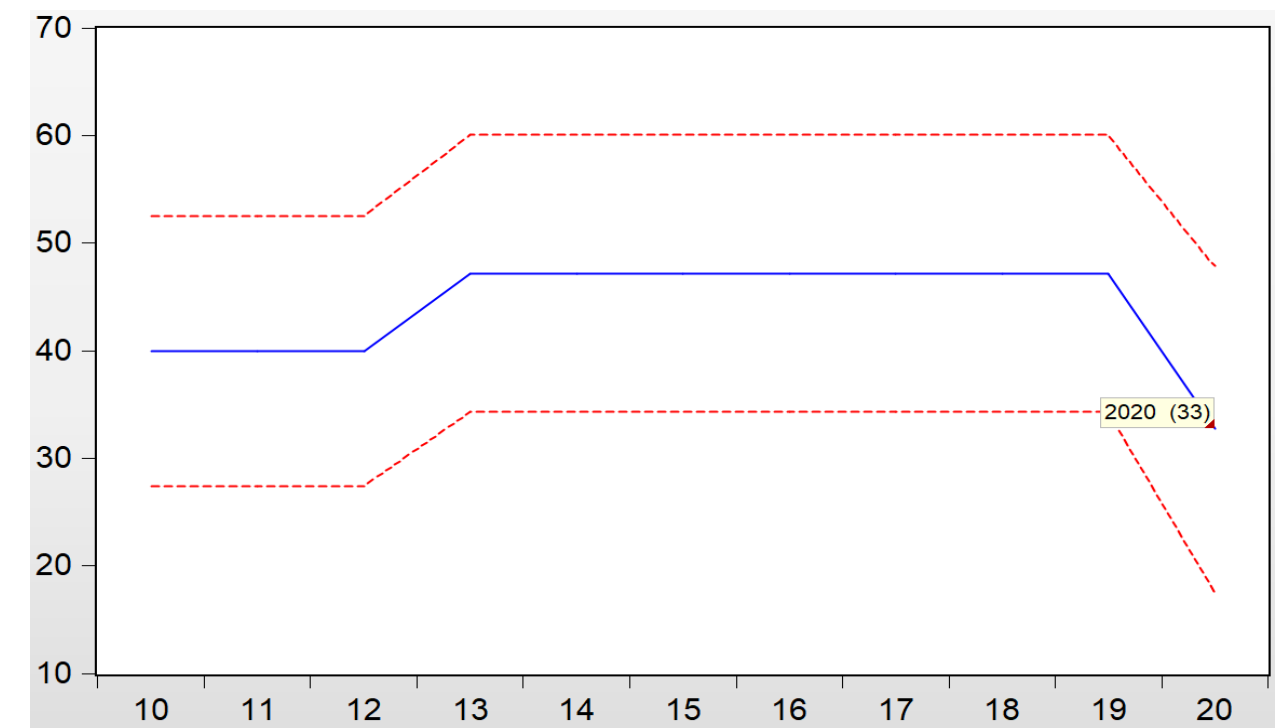

Figure 1: The dynamics of the Electoral Participation 2012-2020 with confidence level $p<0.01$

Starting through these assumptions we can estimate the likelihood level for electoral participation in different Parliamentary and Presidential elections as: and

Let be $\mathrm{X}=$ electoral participation with $\mu=42.84, \sigma=8.08$ and p- probability of $\mathrm{X}$, $P: X \rightarrow[0 ; 1]$

$$
\text { with } \int_{0}^{1} p(x) d(x)=1, \text { and } Z=\frac{x-\mu}{\sigma}
$$

We estimate with $\mathrm{p}=0.95$ that electoral participation could have a decreasing rate until the lowest value of the confidence level of $35.75 \%$ of the voters.

\section{Posterior Distribution Characterization for One-Sample Mean}

\begin{tabular}{|c|c|c|c|c|c|c|}
\hline & \multicolumn{3}{|c|}{ Posterior } & & \multicolumn{2}{|c|}{ 95\% Credible Interval } \\
\hline & & & & & Lower & Upper \\
\hline & $\mathrm{N}$ & Mode & Mean & Variance & Bound & Bound \\
\hline $\begin{array}{l}\text { Electoral } \\
\text { Participation }\end{array}$ & 5 & 42,8460 & 42,8460 & 13,081 & 35,7573 & 49,9347 \\
\hline
\end{tabular}




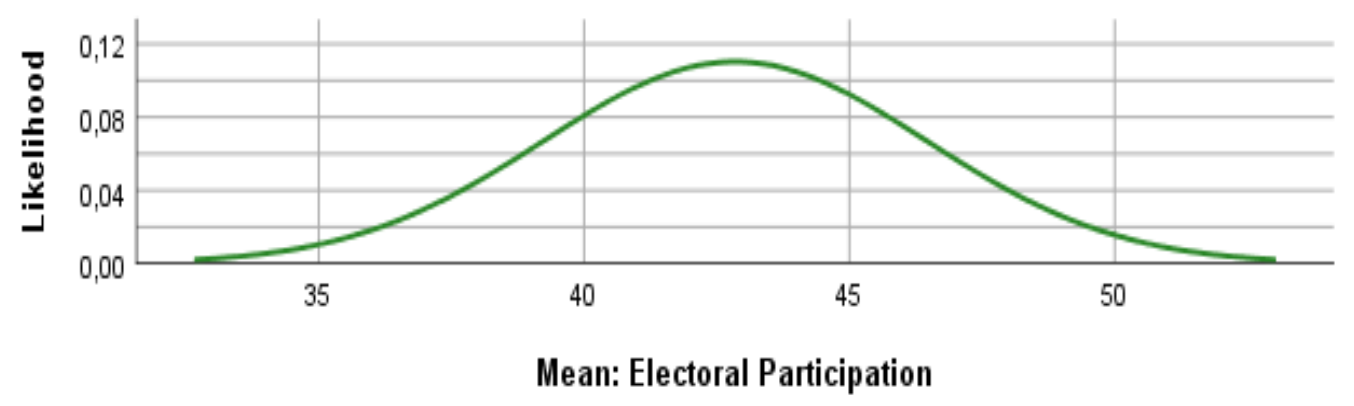

Figure 2: Bayesian Statistics for estimating Electoral Participation

If the differential equation of $\mathrm{X}=$ electoral participation is:

$\frac{d}{d x}(\ln (x))$, and $\ln \left(x_{i}\right)$ - growth rate of electoral participation, we estimate that the variation rate of the voter turnout $(\mathrm{VT})$ is:

$V T=\sum_{i=1}^{n} \ln (x i)$

we obtain several scores:

\begin{tabular}{llll}
\hline YEAR & TYPE OF ELECTIONS & VOTER TURNOUT & $\ln (\mathrm{Xi})$ \\
\hline 2012 & Parliamentary Elections & 41.76 & 3.731 \\
2014 & Presidential Elections & 53.18 & 3.973 \\
2016 & Parliamentary Elections & 39.79 & 3.683 \\
2019 & Presidential Elections & 47.66 & 3.864 \\
2020 & Parliamentary Elections & 31.84 & 3.460 \\
\hline
\end{tabular}

$V T=\sum_{i=1}^{n} \ln (x i)=3.731+3.973+3.683+3.864+3.460=18.711$

$V T($ Parliamentary $)=\sum_{\mathrm{i}=1}^{\mathrm{n}} \ln (\mathrm{xi})=3.731+3.683+3.460=10.874$

$V T($ Presidential $)=3.973+3.864=7.837$

In this respect we estimate that the electoral sphere has an important rate of variation from 2012 to 2020 with $18.711 \%$ for both types of elections. Moreover, in the case of Parliamentary elections the rate of variation is 10.874 . In the case of Presidential elections is 7.837. We can observe a high rate of variability in the case of Parliamentary elections from 2012 to 2020. Political distrust and alienation from the traditional ideological spectrum associated with a high level of social polarization and economic factors could be several explanations for the highest rate of variability for legislative elections. 


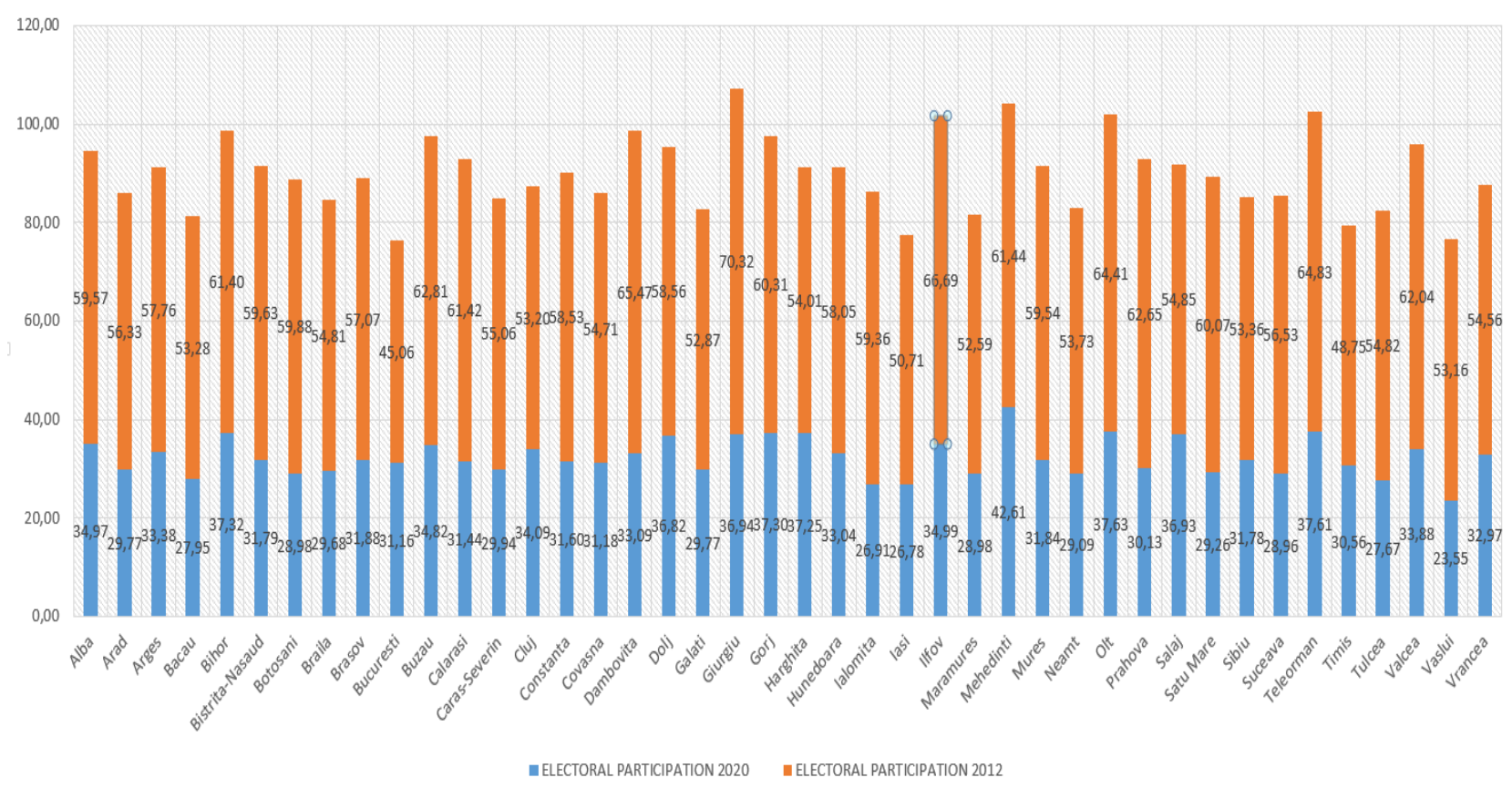

Figure 3: Voter Turnout in Romanian Parliamentary Elections. 2012 and 2020

All these statistical estimations reflect the degradation of the electoral participation rate. This fact is involved in crystalizing the model of political alienation or political "apathy". Political apathy could be related to the low level of political culture and high level of political and social polarization. In a comparative approach we can observe that in 2012 the lowest statistical values for electoral participation were met in București (45.06), Timiș $(48.75 \%)$ and Iași (50.71\%). The highest values are incident in the Southern part of the Romania, in counties like: Prahova (62.65\%), Buzău (62.81\%), Teleorman (64.83\%), Dâmboviţa (65.47\%), Ilfov (66.69\%) and Giurgiu (70.32\%). In contrast, in 2020 we can observe very low rates (Quartile $1=29.26 \%$ ) of electoral participation in Parliamentary Elections in Moldova Region with counties as: Vaslui (23.55\%), Iași (26.78\%), Bacău (27.95\%), Suceva (28.96\%), Botoșani (28.98\%), Neamț (29.09\%). Satu Mare (29.26). The highest values of the voter turnout are registered in Q3 (Quartile 3=34.94\%), in which we can integrate counties as: Alba (34.97\%), Ilfov (34.99\%), Sălaj (36.93\%), Olt (37.63\%), Mehedinți (42.61) and other several counties from the Southern part of the Romania. In both cases, 2012 and 2020, in Bucharest the voter turnout for legislative elections has lowest values. 

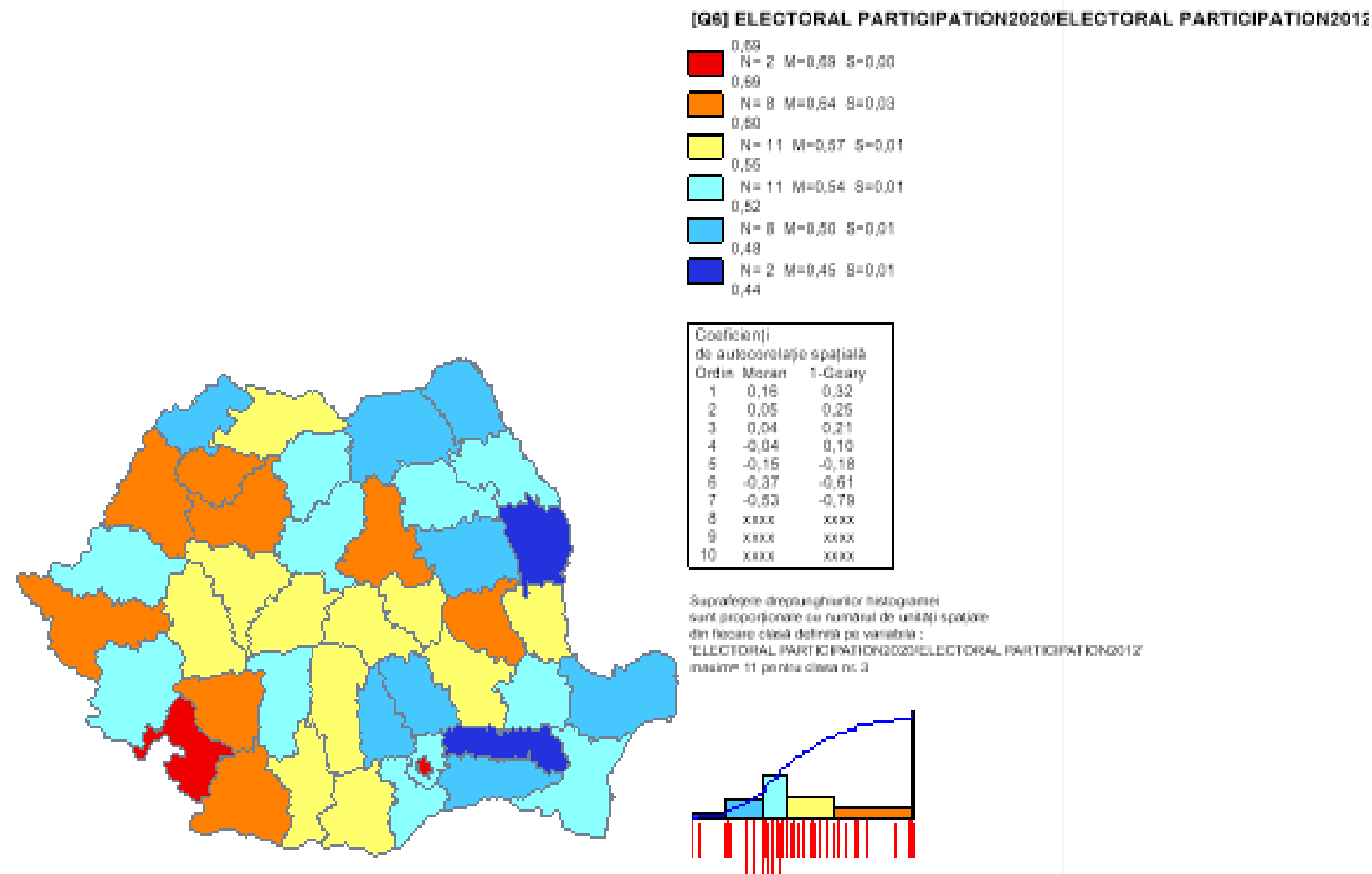

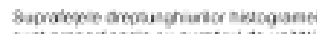

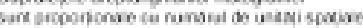

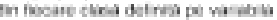

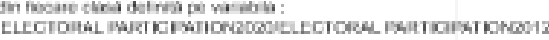

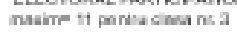
$2020 / 2012$.

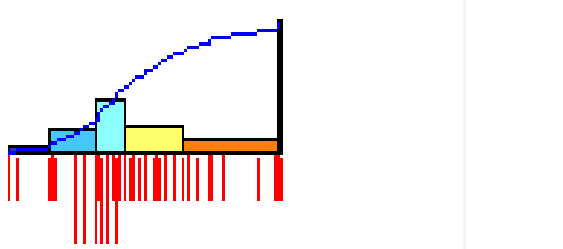

Figure 4: Geographical representation of the Voter Turnout in Romanian Parliamentary Elections

Another indicator which we have estimated is the relation between voter turnout in Parliamentary Elections in 2020 and 2012. If V1 is represented by voter turnout in 2012 and V2 by voter turnout in 2020 we estimate the ratio of the voter turnout (V) is:

$V=\frac{V 2}{V 1}$, where $V \in R-\{0\}$

In the geographical distribution of the voter turnout we observe several cleavages: West-East and North-South. In this meaning we observe high values of the indicator in the West regions as: Oradea, Arad, Cluj, Sălaj and very low rates of the ratio indicator in Moldova. In most part of the counties we register low values. Middle values of the indicator are observed in the central part of the country, in Transilvania. We can deduce that Western counties and Transilvanian Region is more consequent in electoral participation than other administrative units.

Beyond the geographical distribution of the voter turnout, we are interested to observe the relation between political culture and political polarization in shaping electoral behavior. In this context, the cultural variable has the average 4.43 with $\sigma=0.43$, which is characteristic for hybrid political regimes. The main particularity of the political culture is the mix between parochial elements and subject culture (Almond \&Verba, 1996). 


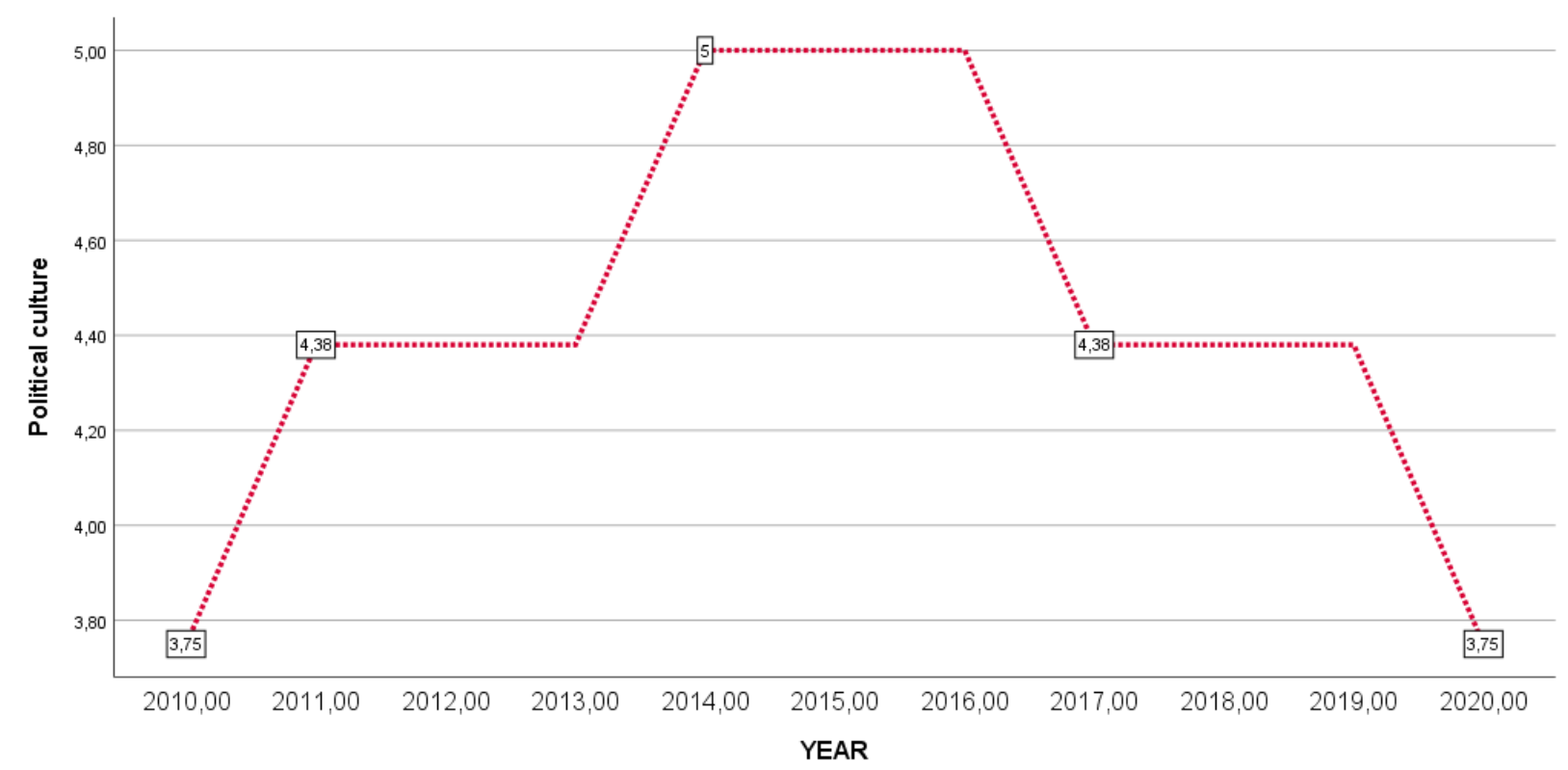

Figure 5: Political Culture in Romania 2012-2020

In conditions in with Romanian political system is characterized by a hybrid cultural model, we have estimated the dynamics of the political polarization and its relevance for understanding the electoral behavior.

\begin{tabular}{|c|c|c|c|c|c|c|c|c|c|c|}
\hline \multirow[b]{3}{*}{ Model } & & \multicolumn{5}{|c|}{ Standardized } & & & & \\
\hline & & \multicolumn{2}{|c|}{ Unstandardized Coefficients } & \multicolumn{3}{|l|}{ Coefficients } & \multicolumn{2}{|c|}{$95,0 \%$ Confidence Interval for B } & \multicolumn{2}{|c|}{ Collinearity Statistics } \\
\hline & & B & Std. Error & Beta & $t$ & Sig. & Lower Bound & Upper Bound & Tolerance & VIF \\
\hline \multirow[t]{5}{*}{1} & (Constant) & 17,072 & 4,661 & & 3,662 & ,011 & 5,666 & 28,478 & & \\
\hline & Political polarization & $-5,485$ & 1,924 &,- 690 & $-2,850$ &, 029 & $-10,193$ & -776 &, 684 & 1,461 \\
\hline & On line Media &, 327 &, 458 & .221 &, 713 &, 503 & -795 & 1,448 &, 418 & 2,394 \\
\hline & Polarization of society &,- 005 &, 375 &,- 006 & -013 & ,990 & -923 & ,913 & .221 & 4,525 \\
\hline & Deliberative Democracy Index & 2,072 & 1,216 &, 510 & 1,704 & ,139 & -904 & 5,047 & .447 & 2,235 \\
\hline
\end{tabular}

a. Dependent Variable: Political culture

Figure 6: Regression Model for Political Culture

The nexus between political culture and electoral behavior could be analyzed starting from several predictors of the cultural model. In this respect, the equation of regression estimates with $\mathrm{R}^{2}=0.76, \mathrm{p}<0.05$ that there is a significant variable which could predict the evolution of the cultural pattern: political polarization $(\beta=-0.690, p=0.029)$. Thus, a single variable explain the level of political culture in a negative but statistically significant correlation. The increased level of political polarization is related to a low level of political culture. High level of political and social polarization and fragmentation could interfere with the individuals' ability of interaction with the political regime in a model based on participative political culture. High levels of polarization are observed, in the scientific literature, to be associated with radical attitudes and post-authoritarian cultural model.

For understanding the influence of the political polarization in the cultural environment we use as social filter the selective exposure of the voters to the on-line news about national politics. In this respect, we observe that on-line media, as it is expressed in the 
theoretical part, has an important impact in shaping social and political polarization. The supposition is that the selective exposure to the on-line media could determine polarized attitudes and behaviors related to political space. Empirically, we have observed an increased level of the on-line media, moreover with political partisanship, which interferes with voters' beliefs and ideology. The model which we estimate suggests that there is an important shift in voters' beliefs and behavior which transcends the limits of the sociotropic and ideological perspectives. If, traditionally we have in the Romanian political system sociotropic voters interested in maximizing economic benefits, the last decade presents a model of political alienation, generated by the cultural model and social polarization. In this context, we can remark the dissolution of the ideological vote and a subtle transformation of the electoral sphere into a space of political apathy. In this radiography, we should mention the role played by the on-line media exposure, social media and other digital networks which have created a polarized model of society. The lack of consensus and deliberation are the main symptoms of this kind of political polarization and post-authoritarian culture, in which there are limited interactions between citizens and political system.

For testing the influence of the on-line media on the political culture and political polarization we estimated the relationship between variables in a 3D model. In this space, we estimate that $R^{2}=0.784$, which signifies a middle association between the increased level of on-line media, high level of political polarization and hybrid model of political culture, based on the agglutination between parochialism and dependent culture.

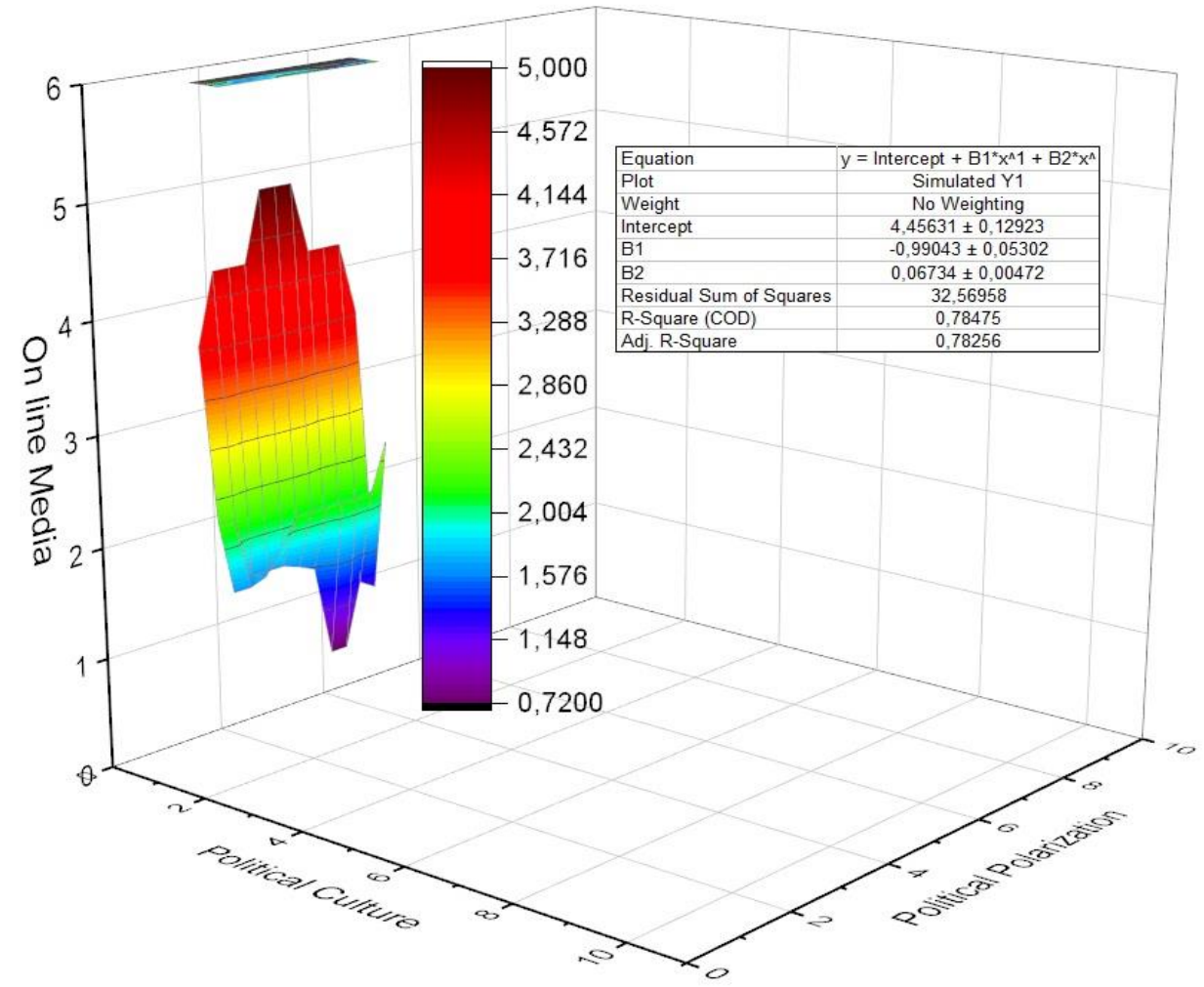

Figure 7: Vector space for: Political culture. Political Polarization and On-line Media

Synthesizing, we confirm several points from the scientific literature, that political polarization and political culture are vectors for political or electoral behavior. The main particularity of the Romanian electoral behavior is political apathy translated through a decreased rate of political and electoral participation. Beyond personal or individual reasons for political action, we argue that the cultural model is the most important endogenous 
variable for understanding and predicting the evolution of participation, deliberation and democratic regime.

\section{Conclusion}

One of the main important problem in the democratic process is represented by participative political behavior. The last decade is characterized, at the global level, by the decreased level of democracy. International studies elaborated by Freedom House, The Economist, V-Democracy Institute observe several challenges for democratic order. In a particular case, this study presents the situation of the participative democracy in terms of electoral behavior (Voter Turnout) in Romanian political system. Data collected from the official statistics presents the Romanian political system in terms of "flawed democracy". This borderline model is explained by historical past, cultural heritage and challenges and changes in the social structure. The endogenous variable which we test in relation with political behavior is represented by political culture. The mix between parochial and subject culture is strongly related to social and political polarization. If, generally speaking, political polarization is involved in radical attitudes and behaviors, in Romanian political system we determine that political polarization and cultural patterns are related to political apathy and distrust in political actors. Moreover, the evolution of the digital media is related to the decreased level of political participation and high levels of social and political polarization. Empirical findings suggest differences in political behavior at the geographical level, mediated by cultural values, social fragmentation and civic interest for solving, in a democratic manner, public affairs.

\section{References}

Acemoglu, D., \& Robinson J. (2006). Economic Origins of Dictatorship and Democracy. Cambridge: Cambridge University Press.

Almond G., \& Verba S. (1996). Cultura Civică, Atitudini politice şi democraţie în cinci naţiuni. București: Ed. Du Style.

Almond, G., Powell Jr G., Strøm, K, \& Dalton, R. (2004). Comparative Politics Today, A World View. New York: Pearson Longman.

Anheier, K. H. (2004). Civil Society, Measurement, Evaluation, Policy. UK: Earthscan from Routledge.

Antunes, da Silva R. J. (2010). Theoretical models of voting behaviour. Excedera, 4, 145170.

Arbatli, E., \& Rosenberg, D. (2020). United we stand, divided we rule: how political polarization erodes democracy. Democratization, 28(2), 285-307. https://doi.org/10.1080/13510347.2020.1818068

Aslund A. (2010). Cum s-a construit capitalismul. Iași: Ed. Tipo Moldova.

Baila, C., Guaya, B., Maloneya, E., \& Combsa, A. et.al. (2020). Assessing the Russian Internet Research Agency's impact on the political attitudes and behaviors of American Twitter users in late 2017. PNAS, 117 (1), 243-250.

Beck, U. (2007). Realistic cosmopolitanism. How do societies handle otherness. In D. Held, H. Moore (Eds), Cultural Politics in a Global Age, Uncertainty, Solidarity and Innovation, Oxford: Oneworld Publications, 61.

Dahl, A. R., Shapiro, I., \& Cheibub, A. J. (2003). The Democracy Source Book. Cambridge, Massachusetts, London: The Massachusetts Institute of Technology.

Dahl, A. R. (2000). Poliarhiile. Participare şi opoziţie. Iași: Editura Institutul European.

Dahl, A. R. (2002). Democraţia şi criticii ei. Iași: Editura Institutul European. 
Dalton, R., \& Klingemann, H.D. (2011). Overview of Political Behavior: Political Behavior and Citizen Politics. In H.D. Klingemann (Ed.), The Oxford Handbook of Political Science (pp. 322-344). Oxford: Oxford University Press.

Edwards, M. (2009). Civil Society. Cambridge: Second Edition, Polity Press.

Henderson, P., \& Vercseg, I. (2010). Community Development and Civil Society Making Connections in The European Context. UK: The Policy Press, University of Bristol.

Hoewe, J., \& Peacock, C. (2020). The power of media in shaping political attitudes. Current Opinion in Behavioral Sciences, 34, 19-24.

Hout, M., \& Maggio, C. (2021). Immigration, Race \& Political Polarization. Daedalus, the Journal of the American Academy of Arts \& Sciences, 150(2), 40-55. https://doi.org/10.1162/daed_a_01845

Inglehart, R., \& Welzel, C. (2005). Modernization, Cultural Change and Democracy, The Human Development Sequence. Cambridge: Cambridge University Press.

Johnson, T., Kaye, B., \& Lee, A. (2017). Blinded by the Spite? Path Model of Political Attitudes, Selectivity, and Social Media. Atlantic Journal of Communication, 25(3), 181-196. https://doi.org/10.1080/15456870.2017.1324454

Lazarsfeld, P.F., Berelson, B., \& Gaudet, H. (1968). The people's choice: how the voter makes up his mind in a presidential campaign. New York: Columbia University Press.

Levendusky, M., \& Malhotra, N. (2015). Does Media Coverage of Partisan Polarization Affect Political Attitudes? Political Communication, 33(2), 283-301. https://doi.org/10.1080/10584609.2015.1038455

Madison, G. B. (1998). The Political Economy Of Civil Society And Human Rights. London \& New York: Routledge London \& New York.

Mellon, J., \& Prosser, C. (2017). Twitter and Facebook are not representative of the general population: Political attitudes and demographics of British social media users. Research and Politics, 1-9. https://doi.org/10.1177/2053168017720008

Meusburger, P., \& Heike, J. (2001). Transformations in Hungary, Essays in Economy and Society. Heidelberg: Physik-Verlag.

Moss, J. T., \& O'Connor, P.J. (2020). Political correctness and the alt-right: The development of extreme political attitudes. PLOS ONE, 15(10), e0239259. https://doi.org/10.1371/journal. pone.023925

Newton, K, \& Wan Deth, J. (2009). Foundations of comparative politics. Cambridge: Cambridge University Press.

Prior, M. (2013). Media and Political Polarization. Annu. Rev. Polit. Sci, 16, 101-27.

Przeworzki, A. (2001). Democracy and the Market, Political and Economic Reforms in Eastern Europe and Latin America. Cambridge: Cambridge University Press.

Putnam, D. R., Leonardi, R., \& Nanetti, R. (2001). Cum funcţionează democraţia? Iași: Ed. Polirom.

Rekker, R. (2021). The nature and origins of political polarization over science. Public Understanding of Science, 30(4), 352-368.

Song-In, Wang. (2007). Political Use of the Internet, Political Attitudes and Political Participation. Asian Journal of Communication, 17(4), 381-395. https://doi.org/10.1080/01292980701636993.

Tertytchnaya, K., \& Lankina, T. (2020). Electoral Protests and Political Attitudes under Electoral Authoritarianism. The Journal of Politics, 82(1). https://doi.org/10.1086/705815.

Yarchi, M., Baden, C., \& Kligler-Vilenchik, N. (2020). Political Polarization on the Digital Sphere: A Cross-platform, Over-time Analysis of Interactional, Positional, and 
Affective Polarization on Social Media. Political Communication, 38, 98-139. DOI: https://doi.org/10.1080/10584609.2020.1785067

Zhang, W., Johnson, T., \& Seltzer, T., \& Bichard S. (2010). The Revolution Will be Networked: The Influence of Social Networking Sites on Political Attitudes and Behavior. Social Science Computer Review, 28(1), 75-92. 